\title{
Paper Strips Driven Design - Application on Doubly Curved Surfaces
}

\author{
Aleksandar A. Čučaković \\ PhD., Associate Professor \\ University of Belgrade \\ Faculty of Civil Engineering \\ Biljana S. Jović \\ PhD., Docent \\ University of Belgrade \\ Faculty of Forestry \\ Miloš R. Tripković \\ Student \\ University of Belgrade \\ Faculty of Forestry
}

In this paper, we address the challenge of overcoming the problem of developing doubly curved surfaces in product design.

Product design uses two kinds of surfaces, developable surfaces and nondevelopable surfaces, which are also called singly and doubly curved surfaces, respectively. A developable surface has zero Gaussian curvature at all points, while a non-developable surface has non-zero Gaussian curvature at least in some region. Surfaces of many product design object are commonly created as doubly curved shapes to meet requirements of structure and aesthetic.

The problem of creating the planar development of $3 D$ surfaces with double curvature in the product design depends on the shape of the surface and the material of the surface cover. Therefore, the method of deriving a pattern is different when external forces are used in order to generate the plane patterns such as paper strips from the case when the plane shape can stretch or deform to fit on the $3 D$ surface.

Given a three-dimensional object surface, the first step of the fabrication process is flattening or planar development of this surface into a planar shape so that the manufacturer can not only determine the initial shape of the object but also estimate the strain distribution required to form the shape depending on a material.

The paper is analysing and rationalizing doubly curved surface of a given shape by multiple strips of paper glued onto a surface. Results are addressing possibilities of achieving an overall smooth surface and developing a model for the generation of curvature continuous surfaces composed of paper strip surfaces, as well as generating alternative solutions that are in the domain of contemporary product design. The paper illustrates usability and different variations of the proposed design.

Keywords: doubly curved rotational surfaces; geodesic strip models; paper strips; product design;

\section{INTRODUCTION}

There are several ways to generate smooth surfaces which are continuous and each point has its tangential plane. The basic division of the smooth surfaces is on the developable and non-developable surfaces, which are also called singly and doubly curved surfaces. The difference between developable and non-developable surfaces is that with the developable surfaces tangential plane is touching the surface by line, and in nondevelopable surfaces at every point of the surface there is a special tangential plane. All doubly curved surfaces are non-developable, and may be generated in different ways.

Among doubly curved surfaces are rotational surfaces. Special forms of rotational surfaces are seen widely in architecture and design.

Spheres, cylinders, cones and torus are well-known representatives of this surface class.

Received: June 2016, Accepted: November 2016

Correspondence to: Dr Biljana Jović

Faculty of Forestry,

Kneza Višeslava, 11030 Belgrade, Serbia

E-mail: biljana.jovic@ @sfb.bg.ac.rs

doi:10.5937/fmet1702251C

(C) Faculty of Mechanical Engineering, Belgrade. All rights reserved
Rotational surfaces are generated by rotating a planar or spatial curve about an axis. It is recommended that surfaces of revolution may be generated using planar meridian curves rather than arbitrary spatial curves. Meridian curves are symmetric to the rotational axis. Every point of the generating curve describes a circle whose supporting plane lies orthogonally to the axis. Thus, every rotational surfaces carries a set of circles in parallel planes which we call parallel circles [1].

Planes that contain the axis of the rotational surface intersect the surface along congruent planar curves, the meridian curves. The supporting planes of the parallel circles and the meridian planes of the meridian curves are orthogonal. This implies that the meridian curves and the parallel circles also intersect at right angles. They form a net of orthogonal curves on the surface.

The principles of the generation of the rotational surfaces have been used in design and architecture. Smooth rotational surfaces can be frequently found in modern design [2]. However, they are sometimes not suitable for putting design ideas into practise. When constructing actual physical object we often need discrete or semi-discrete model that sufficiently approximates the smooth surfaces that it is designed 
with CAD software. In some cases we have to replace smooth surfaces with appropriate planar faces that may be manufactured in a more convenient way. By substituting the meridian curve with the polyline, one obtains a surface formed by conical or cylindrical strips. If the rotation is discretized it generates polyhedral surface (discrete rotational surface). This surface can be used as a suitable replacement for the original surface whose basic elements can be developed in to the plane.

Doubly curved rotational surface is non-developable surface and as such is unsuitable for coating its surface with smooth straight stripes. In overcoming this specific problem it is necessary to use the geodesic line of the surface. Geodesic curves are the shortest line distances between two points on the surface. Geodesic line is the curve on the surface in which in each point the geodesic curvature is zero.

\subsection{Geometry of doubly curved anticlastic surfaces}

The shape of the contours of surfaces can vary between geometrically regular or irregular, polygonal or curved. Form of the surface is related to the nature of its curves and surfaces generation technique. Depending on the sign of the Gaussian curvature that is defined by the

$$
K g=K_{1} \bullet K_{2}=\frac{1}{r_{1} \bullet r_{2}}
$$

where

$$
K_{1}=\frac{1}{r_{1}}
$$

is the first main curvature, and

$$
K_{2}=\frac{1}{r_{2}}
$$

the second main curvature at the specific point of the surface, it is possible to carry out classification of surfaces in the following manner:

Singly curved surfaces:

$$
\begin{aligned}
& \frac{1}{r_{1} \bullet r_{2}}=0 \\
& \frac{1}{r_{1} \bullet r_{2}}=0
\end{aligned}
$$

when one of the radiuses is infinite

$$
\left(r_{2}=\infty\right)
$$

which is why the Gaussian curvature is zero.

1. Doubly curved surfaces:

(a) Positive-synclastic (elliptic surfaces):

$$
\frac{1}{r_{1} \bullet r_{2}}>0
$$

where the centers of curvature of the two families of curves are on the same side of the surfaces.

(b) Negative-anticlastic (hyperbolic surfaces):

$$
\frac{1}{r_{1} \bullet r_{2}}<0
$$

centers of curvature of one family of curves are located on one side, and the second family of curves have centers on the other side of surface.

Another important definition of the curve is the average curvature given by:

$$
K m=\frac{1}{2}\left(K_{1}+K_{2}\right)
$$

When the principal curvatures $\mathrm{K} 1$ and $\mathrm{K} 2$ are of equal values but with different signs average curvature is equal to zero, thus represents, a special case of surface known as minimal surface.

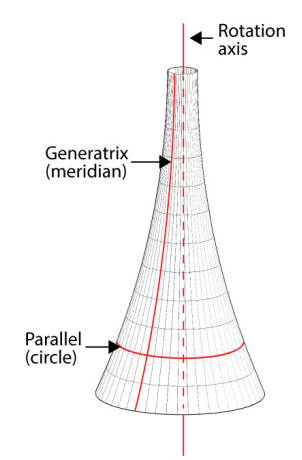

(a)

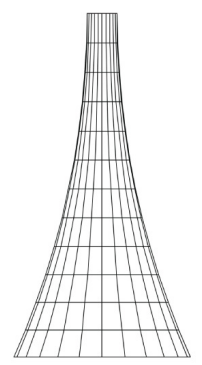

(b)

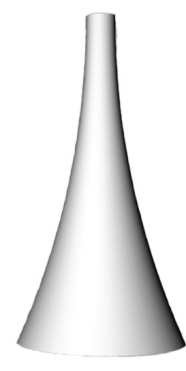

(c)
Figure 1. : (a) Model of design artefact with generatrix (meridian), parallel (circle) and rotation axis, (b) model with net of meridians and parallels, (c) smooth 3D model

\section{MATERIALS AND METHODES}

\subsection{Geometric analysis of the form of the surface}

The paper is using the design artefact as a representative of doubly curved surfaces. In this particular case of doubly curved surface (design artefact) an analysis was performed of its geometric shape and type of surface. Researched doubly curved surface belongs to the type of rotational surface with negative Gaussian curvature. Parallels of the surface are circles of different radius each, whose centers are located on the axis of the surface. Geometric analysis showed that the meridians of the surface are parts of the circle of regular torus whose axis coincides with axis of the researched surface.

Torus is generated by rotating a circle around an arbitrary line. This straight line (rotational axis) has to lie in the plane of the circle. The radius of the meridian of the doubly curved surface is equal to meridian curve radius of the torus. Thus, doubly curved surface is a part of inner part of torus surface.

The main tangents at the point of doubly curved rotational surface are mutually perpendicular tangents of the meridian (curve) and parallel (circle). Two main tangents form a tangential plane of the surface. The main tangents at any point of the surfaces are normal to each other. Normal surface passes through the point at which intersect main tangent and normal to the tangential plane. Normal is contained in the meridian plane and intersects the axis of the surface. The intersection point of the surface normal and the rotational axis is the center of a sphere that contains the surface point. The sphere and the rotational surface are 
tangent along the parallel circle. The main curves at a point of doubly curved surfaces are located in planes of normal cross section and are determined by the main tangents and the normal of the observed point.
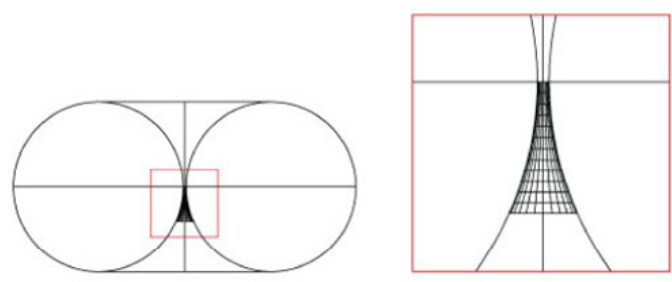

(a)

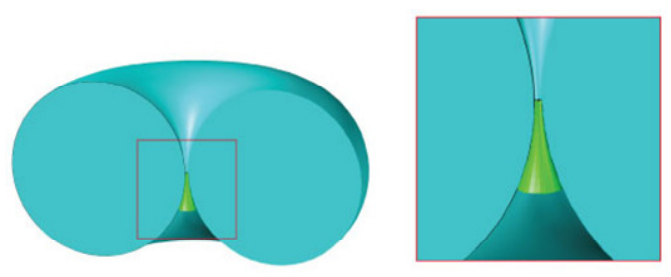

(b)

Figure 2. : (a) Design artefact as part of torus surface, (b) 3D model of design artefact as part of torus surface

The radius of one main curvature at the point of the surface is equal to curvature radius of meridian of the surface at the same point. The radius of other main curvature of the surface is equal to the distance from the surface point to the point of intersection of normal and the axis of the surface (from Meusnier theorem (1776): Center of the parallel's circle through tangent at the point of the circle must be the orthogonal projection of the center of curvature of normal cross-section through the same parallel's tangent).

Geodesic and geodesic strip models were produced in software Rhinocores and its plugin Grasshopper. The software is using generative algorithms, and a graphical algorithm editor tightly integrated with Rhino's 3-D modeling tools. The procces of creating geodesic on doubly curved rotational surface is illustrated in Fig. 4.

\section{RESULTS AND DISCUSSION}

\section{a. Paper strip models}

Because developable surfaces have a number of properties that are used in architecture and design, we can reflect on the approximation of non-developable surfaces by conjoining strips of developable surfaces. A number of curves may be set on a specific surface that can be conjoined by developable surfaces [6]. This procces often results in model whose surface is not smooth enough. Therefore, in procces of forming better detailed model, several curves can be used on surfaces which are close to (or coincide) with the main surface curves.

The possibility to create a surface which is not smooth enough is reduced, because of the position of the strips that needs to be approximately orthogonal to its edge curves, where the strips approximate tangential developable surface [4]. A special case of surface at which this becomes evident is rotational surface. Within rotational surface main curves are its circle curves and meridian curves. Strips limited with circles lie on rotational cones and strips with limited with meridian curves lie on cylindrical surfaces.

\section{b. Cylindrical strip models}

Panels shaped as general cylinders, developable surfaces where all rulings are parallel are used in product design where a smooth surface can be approximated by a cylindrical model. Optimization for cylindrical models is not difficult, since maintaining parallelity of edges automatically implies developability [5]. Cylindirical strips are obtained by cross-section of pencil of planes passing through the axis of rotational doubly curved surface. Resulting strips are mutually equal and are parts of the same cylinder.

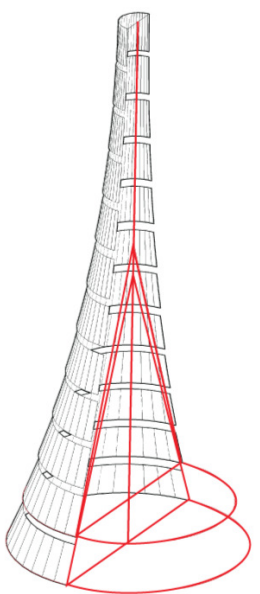

(a)

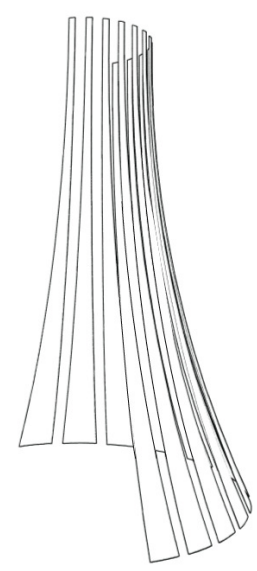

(b)
Figure 3. : Semi-discrete strip surface models (a) conical strip model (b) cylindrical strip model

\section{c. Conical strip models}

A quad mesh is conical if all vertices have an associated right circular cone which is tangent to the faces adjacent to that vertex. When the surface is cross-sectioned with planes normal to the axis of the doubly curved rotational surface obtained strips are parts of cones of different diameters and different inclination of generatrices to a horizontal plane.

\section{d. Geodesic strip models}

Meridians and parallels of a doubly curved rotational surface are geodesic curves. Geodesic (i.e., shortest) curves in surfaces have been employed in architecture and design, to a varying degree of success.

A geodesic curve on a surface is a (locally) the shortest path on surface between two points, and therefore it is also a geodesic on the researched surface. The geodesic curve is mapped to a straight line in the planar unfolding of strip of paper glued on to surface. If we glue a straight paper strip onto a physical surface model it follows along a geodesic and therefore geodesics may guide the alignment of paper strips. A geodesic curve on a smooth surface has osculating planes orthogonal to surface. 


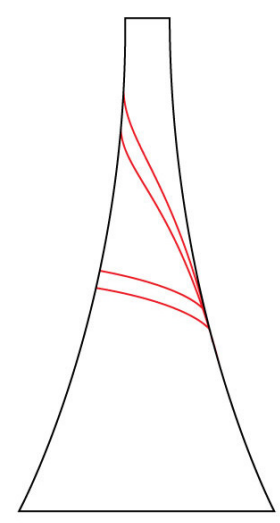

(a)

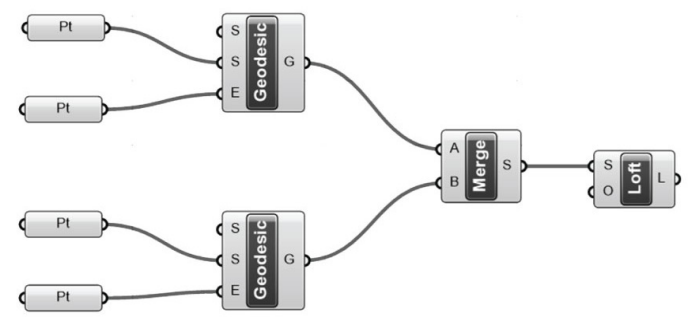

(c)

Figure 4. : Geodesics on doubly curved surface (a) four geodesic lines on design artefact surface (b) two different geodesic strips on design artefact model (c) scheme of elements in Grasshopper in production of geodesics

In the semi-discrete case, we therefore define that a D-strip model is a geodesic model, if the osculating planes of edge curves bisect adjacent strips. Such bisector planes are reasonable planes "orthogonal" to the strip model (which is itself not smooth), if the strip model converges to a smooth surface, those planes converge to exactly orthogonal planes.

It seems feasible to cut them (planar paper strips) out of long rectangular panels. Typically a freeform surface is covered not by one, but by several geodesic D-strip models. In this case the surface can be covered by one geodesic D-strip model, such as conical strip model, as well as cylindrical strip model, but also may be covered with differente families of geodesic strips [3].

Each edge curve of a geodesic model has oppositely equal geodesic curvatures with respect to adjacent strips. Consequently, developing these strips yields oppositely congruent boundaries. The properties of strips imply that the development of the single strip is approximately straight [7].

\section{CONCLUSION}

In this paper, the problem of designing planar paper strip that corresponds to a part of smooth doubly curved surface has been addressed.

The paper, in the first part, analyzes the basic geometry of the design artefact - doubly curved rotational surface, after wich deals with geometrical analysis of the given form and its generation as a part of the surface of the torus.

The introduced method of dealing with the problem of first stage is based on usage of elements of the geodesic and Gaussian curvature. Conical and cylindrical strip models are introduced as an alternative method for generating an initial planar development of doubly curved surfaces.

The paper suggests geodesic strip model as a posible solution for developing, but also skinning (covering surface with glued paper strips) doubly curved rotational surface.

\section{ACKNOWLEDGMENT}

Authors are supported by the Ministry of Education, Science and Technological Development of the Republic of Serbia, Project No. TP 36008.

\section{REFERENCES}

[1] Azariadis P., Aspragathos N., 1997, Design of plane developments of doubly curved surfaces Computer Aided Design, Vol. 29, No. 10, pp. 675665, Great Britain.

[2] Cucakovic A., Nestorovic M., Jovic B., 2010, Free form surfaces structures, University of Belgrade, Serbia, Proceedings Mongeometrija, Belgrade.

[3] Gonzalez-Quintial F., et al., 2014, Freeform surfaces adaptation using planar quadrilateral facets, 16th International conference on geometry and graphics, Innsbruck, Austria.

[4] Maurin B., Motro R., 2013, Textile Architecture. Materiaux Composites Souples en Architecture, Construction et Interieurs, Birkhauser, 13 p.

[5] Postle B., 2012, Methods for creating Curved Shell Structures From Sheet Materials, Buildings, No. 2, pp.424-455, UK.

[6] Pottmann H., et al., 2007. Freeform surfaces from single curved panels, to appear (Siggraph 2008).

[7] Yu G., Patrikalakis N., Maekawa T., 2000, Optimal development of doubly curved surfaces, Massachusetts Institute of Technology, Department of Ocean Engineering, Design Laboratory, Cambridge, MA 02139-4307, USA.

\section{ДИЗАЈНИРАЊЕ ПАПИРНИМ ТРАКАМА - ПРИМЕНА НА ДВОСТРУКО ЗАКРИВЉЕНИМ ПОВРШИМА}

Овај рад се бави могућношћу превазилажења проблема развијања у раван двоструко закривљених површи у процесу дизајнирања производа.

У процесу дизајнирања производа користе се две врсте површи, развојне површи и неразвојне површи, које се, такође, називају једноструко и двоструко закривљеним површима.

Гаусова кривина развојних површи у свакој тачки једнака је нули, док је код неразвојних површи Гаусова кривина ратзличита од нуле па у неким деловима површи Гаусова кривина може да буде позитивна или негативна. Површине многих дизајнпроизвода су често осмишљене као двоструко закривљене површи како би задовољиле структурне и естетске захтеве. 
Проблем развијања у раван двоструко закривљене тродимензионалне површи у дизајну производа зависи од облика површине и материјала производа. Стога, метод проналажења начина за развијање двоструко закривљене површи у раван се разликује, када се спољашња сила користи у стварању површинског обрасца као што је присутно код површи (материјала) које је могуће деформисати, од случаја развијања површи креираних од папирних трака.

Посматрајући површину тродимензионалног објекта, први корак у процесу производње је развијање дизајнираног производа у раван како би произвођач могао да одреди не само иницијални облик објекта, већ и да расподели напрезање потребно за формирање облика зависно од материјала.

У раду се анализира и рационализује двоструко закривљена површ датог облика коришћењем папирних трака залепљених на површину дизајнпроизвода. Резултати истражују могућности постизања приближно глатке површине и развоја модела за генерисање непрекидне криве површи састављене од папирних трака, као и креирања алтернативних решења употребљивих у домену савременог дизајна производа. Рад илуструје могућност коришћења различитих варијација предложеног дизајна. 